\title{
A DESCOLONIZAÇÃO DA ÁFRICA: NACIONALISMO E SOCIALISMO
}

\author{
Marina Gusmão de Mendonça ${ }^{1}$
}

\begin{abstract}
Resumo: Os impérios coloniais africanos duraram apenas até a década de 1960. Para compreender o processo de desagregação desses impérios, bem como a própria rapidez com que o fenômeno se deu, é necessário considerar dois aspectos fundamentais: primeiramente, as transformações ocorridas nas metrópoles durante o século XX, e que, de certa forma, levaram a uma situação de impossibilidade de manter o colonialismo. Em segundo lugar, é preciso reconhecer que, em grande medida, a independência foi resultado de uma ampla articulação de movimentos de caráter nacionalista, representados pelas correntes ligadas à negritude, ao pan-africanismo e ao panislamismo. Nesta articulação, as ideias socialistas exerceram importante papel, e a União Soviética (URSS) forneceu grande apoio aos movimentos de libertação. O auxílio soviético se prolongou após a independência, até pelo menos o fim da década de 1970. E, depois de dois decênios de grave crise econômica e social, a ajuda externa tem vindo da China.
\end{abstract}

Palavras-chave: África, Pan-africanismo, Socialismo, União Soviética, China

\begin{abstract}
African colonial empires only lasted until the 1960s. In order to understand the process of disintegration of these empires, as well as the very rapidity with which the phenomenon occurred, two fundamental aspects need to be considered: first, the transformations that occurred in the colonial metropolises during the XXth century and which, in a way, led to a situation of impossibility of maintaining colonialism. Secondly, it must be acknowledged that, to a large extent, independence was the result of a broad articulation of nationalist movements, represented by Negritude, pan-Africanism and pan-Islamism. In this articulation, the socialist ideas played an important role, and the Soviet Union (USSR) provided great support to the liberation movements. Soviet aid extended after independence until at least the late 1970s. And after two decades of severe economic and social crisis, foreign aid has come from China.
\end{abstract}

Key words: Africa, Pan-Africanism, Socialism, Soviet Union, China

1 Bacharel em História e em Direito pela Universidade de São Paulo (USP); Mestre e Doutora em História Econômica pela Faculdade de Filosofia, Letras e Ciências Humanas da Universidade de São Paulo (FLCH-USP); possui pós-Doutorado em Ciências Sociais pela Faculdade de Filosofia e Ciências da Universidade Estadual Paulista (UNESP) - campus de Marília; Professora Adjunta do Departamento de Relações Internacionais da Escola Paulista de Política, Economia e Negócios (EPPEN) da Universidade Federal de São Paulo (UNIFESP) - Campus Osasco; Professora Colaboradora do Curso de Pós-Graduação em Ciências Sociais da Faculdade de Filosofia e Ciências da Universidade Estadual Paulista (UNESP) - Campus de Marília (e-mail: marinamendonca@uol.com.br). 
Os impérios coloniais africanos, surgidos a partir da Conferência de Berlim, em 1885, duraram apenas até a década de 1960, quando, então, entraram em colapso, desaparecendo por completo na década de 1970. Apenas as fortificações brancas na África do Sul, que mantinha também soberania sobre a Namíbia, permaneceram, sendo, no entanto, eliminadas na década de 1990.

Para compreender o processo de desagregação desses impérios coloniais, bem como a própria rapidez com que o fenômeno se deu, é necessário considerar dois aspectos fundamentais: o primeiro deles é o reconhecimento de que, em grande medida, a independência foi resultado de uma ampla articulação de movimentos de caráter nacionalista, representados pelas correntes ligadas à negritude, ao pan-africanismo e ao pan-islamismo. Nesta articulação, as ideias socialistas exerceram importante papel. Em segundo lugar, não podemos esquecer das próprias transformações ocorridas nas metrópoles durante o século XX, e que, de certa forma, levaram a uma situação de impossibilidade de manter o colonialismo.

\section{A Exploração Do Continente E Os Abalos No Sistema Colonial}

Desde o século XV, quando se iniciou a penetração europeia na África, até o século XIX, quando ocorreria a efetiva partilha do território, o continente foi-se integrando à economia mundial. Nos primeiros tempos, não houve o estabelecimento de um controle direto sobre as atividades cotidianas dos africanos, ocorrendo apenas contatos que permitiam à Europa se beneficiar das riquezas extraídas, principalmente por intermédio do tráfico negreiro, que se tornou um dos setores mais importantes do comércio mundial. A integração se daria, portanto, de forma periférica e dependente em relação à economia europeia. Somente a partir do final do século XIX, quando ocorreu efetivamente a partilha da África, a dominação se imporia de maneira irrefutável (DESCHAMPS, 1961).

As formas e os instrumentos pelos quais a Europa afirmou seu predomínio, entretanto, atravessariam diversas fases, determinadas, em grande medida, pela própria evolução dos acontecimentos no continente europeu. Assim, o período compreendido entre a década de 1880 e o final da Primeira Guerra Mundial, em 1918, pode ser considerado como a primeira etapa da imposição da dominação. Nessa ocasião, o colonialismo e as transformações dele decorrentes foram introduzidos de forma gradual, embora sempre de maneira violenta. Num primeiro momento, isto é, entre 1880 e 1900, deu-se a conquista efetiva do território e a sujeição militar. Já na etapa 
subsequente, ou seja, de 1900 a 1918, verificou-se a necessidade de delimitar os territórios pertencentes a cada uma das metrópoles, bem como estabelecer a ocupação efetiva (FREUND, 1998).

A segunda fase da dominação é aquela em que se deu a consolidação da economia colonial, estendendo-se de 1918 - quando ocorreu a segunda partilha da África, dado que a administração dos territórios germânicos foi transferida a outros países em virtude da derrota alemã - ao final da Segunda Guerra Mundial, em 1945. Num primeiro período, entre 1920 e 1930, a economia colonial adquiriria capacidade de se desenvolver por meio de impulsos endógenos, e foi caracterizada pela adoção de um sistema monetário, pela formação de monopólios e cartéis e pela imposição de normas tributárias que atingiam a maior parte da população das colônias. Já na fase compreendida entre o colapso de 1929 e o final da guerra, época em que as economias metropolitanas procuravam obter recursos para superar a depressão mundial, ocorreria uma piora significativa das condições de vida dos povos das colônias, com o recrudescimento da coerção e a redução dos serviços sociais.

Finalmente, no período posterior à Segunda Guerra Mundial, e com o objetivo de aprofundar o sistema de exploração colonial, ao mesmo tempo em que se procurava conter os crescentes movimentos nacionalistas, as metrópoles buscaram elaborar planos de desenvolvimento para o continente africano. Houve, nessa época, um aumento da participação das colônias na economia mundial, embora as tensões políticas se avolumassem.

O primeiro grande abalo no sistema colonial ocorreu no período compreendido entre 1914 e o fim da Segunda Guerra Mundial. O morticínio das duas grandes guerras, permeado pelo advento da Revolução Russa, em 1917, pela depressão iniciada em 1929 e pelo avanço do nazi-fascismo, provocou uma fratura na confiança anteriormente depositada na suposta missão civilizatória europeia. Por outro lado, a destruição dos países europeus, sobrepujados economicamente pelos Estados Unidos (EUA), levou ao declínio da capacidade das antigas potências de manterem integralmente o domínio colonial (KI-ZERBO, s.d., v. 2).

Todavia, e apesar de destruídas pelo conflito, as nações europeias retomariam, após a Segunda Guerra Mundial, a justificativa anteriormente apresentada para a dominação, isto é, a de que os brancos teriam como missão levar a civilização ocidental a povos que supostamente ainda viviam em situação de barbárie. Mas o próprio sistema colonial havia provocado mudanças profundas nas colônias, gerando contradições difíceis de serem superadas. 
De fato, a criação de um sistema educacional nas colônias africanas havia engendrado o surgimento de uma elite educada, que não mais se conformava com a situação de dominação. Por outro lado, a introdução de elementos modernizadores - tais como meios de transporte (rodovias e ferrovias), novas técnicas agrícolas e de mineração, aproveitamento de fontes diversas de energia, instalação de indústrias, expansão da economia monetária e de mercado, a busca por mão de obra assalariada e a propagação do cristianismo -, havia provocado modificações profundas na economia e na sociedade africanas, gerando demandas até então inexistentes. A partir dessas alterações, os próprios africanos passaram a querer realizar mudanças, criando-se as condições para o desenvolvimento do nacionalismo.

$\mathrm{Na}$ década de 1950, com o avanço dos movimentos nacionalistas e o acirramento dos conflitos, além da necessidade de orientar os gastos para a reconstrução europeia, os dirigentes metropolitanos perceberam que não mais havia vantagem em ignorar as pretensões à independência, principalmente levando-se em conta o fato de que os objetivos iniciais que levaram à construção dos impérios coloniais haviam sido plenamente atingidos. Depois de décadas de colonialismo, as empresas européias já detinham o pleno controle dos mercados e dos recursos africanos, podendo deles se aproveitar em benefício próprio e de seus aliados. Por outro lado, e dada a imensa defasagem tecnológica, era evidente que esse aproveitamento era quase inevitável e irreversível, e a tentativa de manter a dominação pela força somente reduziria os potenciais benefícios econômicos. Como bem resumiu Bill Freund,

\begin{abstract}
a descolonização foi um processo histórico tão rápido e tão complexo quanto a partilha no final do século XIX. Suas causas estão, em parte, fora da África, na mudança da correlação de forças políticas internacionais e, também, nas transformações estruturais das necessidades do capital, que agora tinha muito menos interesse na extração de riquezas que caracterizou o sistema colonial na África no início. Em parte, as negociações de independência atingiram o estágio de uma nova aliança entre a emergente classe dominante nativa e os negócios do ocidente. Essa nova classe é uma criatura do colonialismo. (...) A grande onda de resistência popular surgida nas décadas de 1940 e 1950 tornou as colônias africanas muito mais difíceis de administrar. Foi esse movimento que transformou as pequenas associações nacionalistas do período anterior à guerra em agências políticas dinâmicas de luta contra o poder estatal (FREUND, 1998, p. 202-203)
\end{abstract}

Verifica-se, pois, que o processo de independência foi resultado da confluência entre a pressão exercida pelos movimentos nacionalistas de um lado, e o desinteresse e/ou a incapacidade de as metrópoles manterem o jugo, de outro. Na realidade, 


\begin{abstract}
os poderes coloniais tinham que contabilizar os custos da repressão ao nacionalismo e da modernização do colonialismo, que cresceram com o aumento da população. Os benefícios de manter o poder se tornaram duvidosos, a partir do momento em que a Europa se recuperou economicamente na década de 1950. Os tecnocratas franceses começaram a pensar nas colônias meramente como complementos para os setores mais dinâmicos da indústria. Os oficiais britânicos concluíram, em 1957, que faria pouca diferença se as colônias se tornassem independentes. Muitos homens de negócios concordaram: sua prioridade era ter boas relações com quem quer que estivesse no poder. Na década de 1950 , portanto, era desvantajoso resistir ao nacionalismo (ILIFFE, 1995, p. 246).
\end{abstract}

E nesse processo, dois conjuntos de ideias seriam extremamente relevantes: o primeiro deles diz respeito ao surgimento de uma consciência africana, por meio do desenvolvimento do panafricanismo. O segundo refere-se à difusão das ideias socialistas, que apontavam para uma perspectiva de libertação dos povos oprimidos desde o advento da Revolução Russa, bem como ao auxílio da União Soviética (URSS) nas lutas pela independência do continente. Passemos, pois, a uma breve análise da organização do movimento pan-africanista.

\title{
O SURGIMENTO DE UMA CONSCIÊNCIA AFRICANA: A CONCEPÇÃO PAN- AFRICANA
}

Conforme assinalado anteriormente, a compreensão do processo de independência das colônias africanas deve considerar o desenvolvimento das ideias contidas no pan-africanismo, além de ter em conta também a questão do racismo. Com efeito, a violência da dominação só pode se justificar, do ponto de vista ideológico, pela ideia da superioridade de um povo em relação a outro e, portanto, da necessidade de civilizar. Como bem assinalou Albert Memmi, “o racismo faz parte de todos os colonialismos em todas as latitudes. Não é uma coincidência: o racismo resume e simboliza a relação fundamental que une colonialista e colonizado” (MEMMI, 1967, p. 68).

Os espanhóis já haviam feito isso no início do século XVI, com relação à conquista e ao extermínio das populações indígenas da América (FERRO, 1996). Do mesmo modo, foi isso que fizeram os europeus a partir do final do século XIX. Contudo, é preciso diferenciar alguns aspectos do racismo dos espanhóis em relação aos indígenas no século XVI, e aquele assumido pelos europeus no século XIX para justificar a dominação da África. Os primeiros procurariam respaldo predominantemente na religião católica e na necessidade de levar aos selvagens o conhecimento da verdadeira fé e do Deus cristão. Quanto aos segundos, fundamentariam suas concepções num suposto cientificismo, que tem como um de seus maiores expoentes Herbert Spencer (SPENCER, 
1963). Para ele, as ideias de Charles Darwin comprovariam a superioridade dos europeus, que haviam se mostrado mais aptos na luta pela sobrevivência. Porém, é preciso frisar que, tanto nos espanhóis do século XVI como nos europeus do século XIX, há um forte componente racista.

\begin{abstract}
A raça foi uma tentativa de explicar a existência de seres humanos que ficavam à margem da compreensão dos europeus, e cujas formas e feições de tal forma assustavam e humilhavam os homens brancos, imigrantes ou conquistadores, que eles não desejavam mais pertencer à mesma comum espécie humana. Na ideia de raça encontrou-se a resposta dos boeres à 'monstruosidade' esmagadora da descoberta na África - todo um continente povoado e abarrotado de selvagens (...). Dessa ideia resultaram os mais terríveis massacres da história: o extermínio das tribos hotentotes pelos boeres, as selvagens matanças de Carl Peters $^{2}$ no Sudeste Africano Alemão, a dizimação da pacata população do Congo reduzida de uns 20 milhões para 8 milhões; e, o que é pior, a adoção desses métodos de 'pacificação' pela política externa europeia (...) (ARENDT, 1989, p. 215).
\end{abstract}

Como se vê, no período compreendido entre o final do século XIX e o início do século XX, há, no mundo ocidental, uma profunda contradição entre as ideias de liberdade e igualdade, nascidas no bojo da Revolução Francesa, e as justificativas empreendidas para a dominação, baseadas no darwinismo social. Porém, "se o argumento da desigualdade é fundado na raça, essa ideia torna-se primordial para unir os que, embora assemelhados por sua origem, apresentam especificidades históricas particulares" (HERNANDEZ, 2002, p. 139). E é isso que explica o surgimento do movimento pan-africanista, para o qual haveria uma identidade entre todos aqueles com uma origem comum, no caso, a "Mãe África".

Assim, no período compreendido entre 1880 e 1935, ocorreu o desenvolvimento da ideia de uma ligação profunda entre africanos e negros americanos, que se manifestaria em diversos movimentos: 1) retorno de negros para o território de seus antepassados, ou seja, a África; 2) evangelização dos povos africanos, conduzido por missionários norte-americanos; 3 ) matrícula de estudantes africanos em escolas e universidades americanas para negros; 4) contato de africanos com o mundo negro na América; e 5) persistência e transformação de valores culturais africanos na América.

\title{
EVOLUÇÃO DO MOVIMENTO PAN-AFRICANISTA: A AÇÃO DE MISSIONÁRIOS
}

Uma das primeiras manifestações dessa ligação entre africanos e negros americanos data da

2 Carl Peters (1856-1918) foi um representante do governo alemão nas colônias germânicas da África Oriental. Explorador, político e escritor, defendia ardorosamente o darwinismo social. 
década de 1860, quando Alexander Crummell (1819-1898), um padre negro norte-americano que havia emigrado para a Libéria, discursou perante uma comunidade afro-americana sobre $A$ língua inglesa na Libéria, afirmando que "os africanos 'exilados' pela escravidão no Novo Mundo haviam recebido da divina providência (...) a compensação da posse da língua inglesa” (APPIAH, 1997, p. 19). No discurso, Crummell demonstrava uma profunda admiração pela cultura do branco colonizador, cuja língua considerava um legado extremamente benéfico. Para ele - que havia sido educado dentro dos marcos da sociedade norte-americana, e cuja formação estava profundamente impregnada pelos valores do cristianismo -, a África continuava a ser vista como pagã e selvagem, e todos os seus problemas se resolveriam pela adoção da fé cristã.

No entanto, Crummell entendia haver um destino comum para os povos da África, pelo simples fato de que pertenciam a uma mesma raça. Segundo ele,

as raças, como as famílias, são organismos e ordenações de Deus; e o sentimento racial tal como o sentimento familiar, é de origem divina. A extinção do sentimento racial é tão possível quanto a extinção do sentimento familiar. Na verdade, a raça é uma família (Apud APPIAH, 1997, p. 39).

Portanto, o que tornava a África uma unidade era o fato de ela ser a pátria dos negros. Essas ideias também foram desenvolvidas pelo padre Edward Wilmot Blyden (1832-1912), educador, escritor e diplomata antilhano, que adotara a Libéria como pátria. Para Blyden, os africanos são povos que mantêm grande identidade com os ocidentais, e podem e devem ser cristianizados, pois

não há uma tribo no continente da África, apesar da opinião quase universal em contrário, apesar dos fetiches e amuletos que muitas delas supostamente adoram - não há, afirmo, uma única tribo que não levante as mãos para o Grande Criador. (...) Não há ateus nem agnósticos entre eles (Apud APPIAH, 1997, p. 46).

Em 1889, Blyden foi aos EUA, em nome da American Colonization Society (ACS), para conseguir apoio à emigração de negros norte-americanos para a Libéria. E, entre 1880 e 1900, o bispo norte-americano Henry McNeal Turner (1834-1915) procurou combinar a ideia de necessidade de emigração para a África com o trabalho missionário de evangelização. Segundo Turner, 
nossas principais nações, civilizações, leis, costumes, modos de produção (...) e parar de resmungar, de estar sempre recriminando e de ameaçar o país que o homem branco reivindica e que necessariamente dominará (Apud RALSTON; MOURÃO, 1991, p. 753).

Houve ainda outras iniciativas no mesmo sentido, promovidas, em sua maioria, por líderes religiosos ligados a igrejas protestantes. Uma delas foi a criação, em 1884, da African Methodist Episcopal Church (AME), que realizou diversos congressos sobre a política dos negros americanos em relação à África, além de enviar missionários negros para o continente durante todo o período colonial. Do mesmo modo, em 1896 a Igreja Presbiteriana passou a mandar missionários para Camarões. Também o Reverendo William Henry Sheppard (1865-1927), formado pelo Hampton Institute, procurou incentivar a ida de pastores para o Congo, enquanto os Adventistas do Sétimo Dia enviaram missionários para a Niassalândia. Já na África do Sul, os missionários procuravam matricular negros em escolas americanas, fornecendo também ajuda financeira com o objetivo de promover sua integração na sociedade.

\section{O DESENVOLVIMENTO DA IDEOLOGIA PAN-AFRICANISTA}

Essas atividades constituiriam a base para a articulação de uma ideologia pan-africanista. No entanto, o primeiro grande ideólogo do movimento foi William Edward Burghardt Du Bois (18681963), professor de grego e latim norte-americano, para quem "devemos reconhecer que os seres humanos se dividem em raças". Segundo ele, a raça "é uma vasta família de seres humanos, em geral de sangue e língua comuns, sempre com uma história, tradições e impulsos comuns, que lutam juntos (...) pela realização de alguns ideais de vida” (Apud APPIAH, 1997, p. 53-54).

Vê-se, portanto, que a ideia de raça não mais correspondia a uma concepção biológica, mas sim sócio-histórica. Assim, cada uma das raças teria uma mensagem para a humanidade. E a raça negra teria o dever de transmitir a sua mensagem, motivo pelo qual todos aqueles de origem africana deveriam trabalhar para cumprir essa tarefa. Para Du Bois,

o povo negro, como raça, tem uma contribuição a dar à humanidade que nenhuma outra raça pode dar. Cremos no dever dos norte-americanos de ascendência negra, como um corpo, de manter sua identidade racial, até que se cumpra essa missão do povo negro e que o ideal da fraternidade humana tenha-se tornado uma possibilidade prática (Apud APPIAH, 1997, p. 55). 
Dessa forma, era imprescindível a emigração para a África e a interação entre africanos e negros da América. A partir de então, várias entidades destinadas a promover a emigração de afroamericanos foram criadas, dentre as quais se destacam a African Development Society e a International Migration Society (IMS). O objetivo da primeira era estimular afro-americanos a adquirirem terras e se fixarem na África Centro-Oriental. Já a IMS, enviou cerca de 500 emigrantes para o continente. Contudo, muitos deles retornaram à América com relatos sobre as más condições de vida na África, o que acabou por desestimular os movimentos de apoio à emigração. Apesar disso, a partir de 1900 houve ainda novas tentativas de retomar a bandeira da emigração, inclusive com a criação de periódicos, como é o caso da revista The Crisis. E, entre 1919 e 1923, Du Bois daria novo impulso ao movimento pan-africanista, com a organização de diversos congressos internacionais.

Todavia, a principal iniciativa seria tomada pelo empresário e advogado jamaicano Marcus Mosiah Garvey (187-1940), que conquistaria milhões de negros americanos para a causa africana depois da Primeira Guerra Mundial. Sua mobilização ocorreu com a leitura de Up from slavery, de autoria de Booker Tagliaferro Washington (1856-1915), educador e fundador do Tuskegee Institute, escola surgida no Alabama (EUA) com o objetivo de educar os ex-escravos e seus filhos, e do encontro com Dusé Mohammad Ali (1866-1945), intelectual e ator sudanês, autor de In the land of Pharaos, e que fazia acerbas críticas às políticas inglesa e norte-americana em relação à África. A partir dessas experiências, Marcus Garvey criaria, em 1914, a Associação Universal para o Progresso Negro (UNIA), cujo principal objetivo era promover a emigração como forma de redenção dos negros.

Somos descendentes de um povo sofrido. Somos os descendentes de um povo decidido a não mais sofrer. (...) Não queremos o que pertenceu aos outros, embora os outros sempre tenham procurado privar-nos daquilo que nos pertencia (...). As outras raças têm seus próprios países e é tempo de que os 400 milhões de negros reivindiquem a África para si próprios (Apud RALSTON; MOURÃO, 1991, p. 775).

O projeto de Garvey incluía ainda a criação de escolas técnicas agrícolas e industriais na Jamaica, a organização de uma frota mercante para incrementar o comércio entre negros da África e da América, bem como a constituição de uma nação central para a raça negra, a ser criada na Libéria.

No entanto, o governo da Libéria não aceitou a ideia e, no fim da década de 1920, Garvey 
enviou técnicos à Etiópia para estudar a possibilidade de emigração de afro-americanos para aquele país. A atração pela Etiópia devia-se à oposição de Garvey à elite liberiano-americana que estava no poder, bem como ao fato de este ter sido - juntamente com a Libéria - o único país que até então resistira à dominação colonial. Porém, o governo etíope não se mostrou receptivo, assim como não acatou a proposta do rabino negro de Barbados, Arnold Josiah Ford (1877-1935), que também pretendeu incentivar a emigração para aquele país.

Há que se ressaltar ainda as lideranças exercidas por Booker Washington, que passou, com o tempo, a promover contatos entre africanos e negros americanos, e por Joseph Ephraim Casely Hayford (1866-1930), jornalista, escritor e advogado oriundo da Costa do Ouro que criou, em 1920, o National Congress of British West Africa.

\section{A EXPANSÃO DO MOVIMENTO PAN-AFRICANISTA}

Os contatos frequentes entre africanos e negros americanos levariam à expansão do panafricanismo, com sua transformação em movimento político organizado. Assim, no período compreendido entre 1880 e 1940, houve um intenso intercâmbio cultural, com grande número de alunos das colônias britânicas na África que foram estudar em escolas americanas. Os empresários coloniais incentivavam, na prática, a ida desses estudantes para os EUA, com o objetivo de que adquirissem formação adequada para, de volta à pátria de origem, tornarem-se quadros técnicos e mão de obra especializada (DECRAENE, 1961, p. 218). E, apesar de vários desses estudantes, em seu retorno à África, terem entrado em choque com os compatriotas, muitos se transformariam em grandes lideranças nacionalistas, aderindo aos movimentos pela independência.

Dessa forma, pouco a pouco ocorreria um processo de reafirmação da cultura negra, tanto na Europa como nas Antilhas e na própria África Ocidental, o que levaria ao surgimento do conceito de negritude. Essa ideia tomaria impulso principalmente a partir de ações de africanos e antilhanos francófonos e anglófonos. Os líderes da negritude passariam, então, a desenvolver a noção de que existe um movimento histórico e cultural a partir de uma solidariedade racial entre os negros e que, portanto, todos os africanos e os povos de origem africana têm um patrimônio cultural comum, motivo pelo qual deveriam ser reforçados os laços entre os integrantes do mundo negro.

Dentre os principais expoentes do movimento da negritude, destacam-se: Aimé Fernand 
David Césaire (1913-2008), escritor, poeta e político martinicano; Camara Laye (1928-1980), escritor da Guiné; Festus Claudius “Claude” McKay (1889-1948), poeta jamaicano; e LéopoldSédar Senghor (1906-2001), poeta e escritor do Senegal, primeiro presidente do país (1960-1980), e um dos fundadores do movimento da negritude.

As obras desses escritores e políticos constituiriam um grande marco para o avanço do movimento da negritude. No caso de Aimé Césaire, cujo texto mais conhecido é Cahiers d'um retour au pays natal, a poesia é entendida como instrumento de volta às fontes da negritude. Propõe, para isso, a libertação dos negros das formas tradicionais da cultura ocidental. Do mesmo modo, Camara Laye, cuja principal obra é L'enfant noir, evoca o retorno aos costumes tradicionais, enquanto Claude McKay, autor do poema Se temos de morrer, propõe a unificação do panafricanismo cultural e político, desenvolvendo a ideia de que os negros devem tomar consciência de seus sofrimentos comuns, lutar contra eles e afirmar sua dignidade.

Quanto a Léopold-Sédar Senghor, mostrou-se um dos grandes articuladores da luta contra o domínio europeu e pelo fim do colonialismo que, se trouxeram alguns benefícios da modernidade, também foram responsáveis pela exploração e pela pilhagem do continente durante mais de 300 anos. Segundo ele,

certamente a África Negra é um país de fraca densidade; e sem dúvida que sob a ação eficaz do Serviço de Saúde, a cifra de sua população sobe, como um jovem bambu. O que se esquece é que esta terra foi, durante três séculos, entregue à sanguinária cupidez dos 'negreiros' esclavagistas; e que, sob a ação mortífera do branco, dez milhões de seus filhos foram deportados para as Américas e outras regiões; que duzentos milhões morreram nas caçadas ao homem. O que se esquece, de um modo geral, é que cada 'benefício da colonização' teve seu reverso (...). Deste modo, as usinas, as minas, as estradas de ferro, revelaram-se os melhores propagadores das doenças. Falarei também dos camponeses senegaleses que (...) permitem às grandes companhias lucros anuais de centenas de milhões de francos-ouro, sem outros resultados para eles mesmos que não sejam os de empobrecer suas terras e continuarem tão miseráveis quanto há 50 anos (SENGHOR, 1961, p. 34).

É importante ressaltar também o papel exercido por Frantz Omar Fanon (1925-1961), psiquiatra, cientista político e filósofo marxista francês de origem martinicana, que se destacaria como um dos principais teóricos do anticolonialismo. Fanon rejeitava o conceito de negritude, sustentando que o status de uma pessoa depende de suas condições econômicas e sociais. Acreditava que a violência era a única forma de liquidação da opressão colonial e do trauma cultural do Terceiro Mundo, constituindo uma força de limpeza - uma vez que libertava o nativo do 
seu complexo de inferioridade, do seu desespero e da sua inação -, eliminando-lhe o medo e restaurando-lhe o auto-respeito. Para ele,

\begin{abstract}
durante séculos os capitalistas comportaram-se no mundo subdesenvolvido como verdadeiros criminosos de guerra. As deportações, os massacres, o trabalho forçado, a escravidão foram os principais meios empregados pelo capitalismo para aumentar suas reservas de ouro e diamantes, suas riquezas, e para afirmar seu poderio. Há pouco tempo, o nazismo transformou a totalidade da Europa em verdadeira colônia. Os governos das diferentes nações europeias exigiram reparações e reclamaram a restituição em dinheiro e em gênero das riquezas que lhes tinham sido roubadas (...). Igualmente, dizemos que os Estados imperialistas cometeriam um grave erro e uma injustiça inqualificável se se contentassem em retirar de nosso solo as cortes militares, os serviços administrativos e de intendência, cuja função era descobrir riquezas, extraí-las e expedi-las para as metrópoles. A reparação moral da independência nacional não nos cega, não nos alimenta. A riqueza dos países imperialistas é também nossa riqueza (FANON, 1979, p. 80-81)3.
\end{abstract}

\title{
O SOCIALISMO E O PROCESSO DE INDEPENDÊNCIA DAS COLÔNIAS AFRICANAS
}

Como se viu, o movimento pan-africanista ganhou força a partir da década de 1920, e representou uma enorme contribuição para o desenvolvimento do nacionalismo africano, que se intensificaria depois da Segunda Guerra Mundial, culminando com a independência da maioria dos territórios num curto período, que se estendeu de 1957 a 1968. No entanto, para compreender esse processo, é necessário considerar também o papel dos movimentos socialista e comunista internacionais e a contribuição da URSS para a vitória da luta pela libertação. Nesse sentido, e como salientou Yves Person, a primeira pergunta que se deve fazer é: “como falar do socialismo num continente exclusivamente agrícola, sem proletariado nem capitalismo nacional, fora do caso marginal da África do Sul, e onde as classes sociais nem sempre estavam diferenciadas?" (PERSON, 1984, p. 729).

A esse respeito, o autor lembra que Marx havia admitido a possibilidade de a Rússia passar diretamente da comunidade rural para o socialismo, o que acabaria se confirmando com a vitória da revolução de 1917. De outra parte, os africanos não se conformavam com a perspectiva de assistir à exploração colonial como algo inevitável, elaborando, então, a "teoria de um socialismo africano que se desenvolveria naturalmente a partir das mentalidades e das estruturas originais das sociedades tradicionais, corroídas mas não obliteradas pela colonização" (PERSON, 1984, p. 729).

Yves Person ressalta, porém, que o socialismo é uma doutrina desenvolvida essencialmente

3 FANON, Frantz. Os condenados da terra. Rio de Janeiro: Civilização Brasileira, 1979, pp. 80-81. 
na Europa, onde havia um operariado já constituído e, em grande parte, organizado. E foi exatamente a colonização que possibilitou a sua introdução na África, onde penetrou por meio de intelectuais africanos que haviam estudado na Europa ou tido contato com a cultura ocidental, e que eram, em relação às tradições africanas, já bastante desenraizados. Em consequência, a sua difusão no continente se daria por intermédio de movimentos nacionalistas, como o pan-africanismo e a negritude, estes também baseados em sistemas filosóficos europeus (PERSON, 1984, p. 730).

Esses intelectuais iriam tentar adaptar a teoria socialista à realidade do continente. Com este objetivo, procurariam demonstrar que, na verdade, tratava-se de atualizar antigas tradições africanas. Assim, para os principais teóricos de um "socialismo africano", entre os quais se destacam Léopold-Sédar Senghor, Kwame Nkrumah ${ }^{4}$ e Julius Nyerere ${ }^{5}$, além de algumas lideranças que procuraram colocar em prática essas ideias, como Amílcar Cabral ${ }^{6}$ e Sekou Touré7, "a tradição africana predispõe para o socialismo, em virtude do caráter 'coletivista' (...) das suas sociedades" (PERSON, 1984, p. 730).

Yves Person, contudo, aponta algumas questões importantes a respeito desta "predisposição" africana para o socialismo. Primeiramente, salienta o fato de que, no conjunto da África negra, em geral com baixa densidade populacional, a posse da terra era coletiva, e a unidade de produção coincidia com a unidade social básica (família ou linhagem). Assim, embora não existissem classes definidas de acordo com sua posição no processo de produção, havia desigualdades, baseadas em idade e sexo. O autor destaca ainda que, nas regiões onde existia o Estado, este não intervinha

4 Kwame Nkrumah (1909-1972) foi um dos fundadores do movimento pan-africanista. Com a independência de Gana, em 1957, tornou-se primeiro ministro do país até 1960. Neste ano, foi eleito presidente, cargo que ocupou até 1966, quando foi deposto por um golpe militar. Exilado, jamais voltou a Gana.

5 Julius Kambarage Nyerere (1922-1999), historiador, economista e professor tanzaniano, foi nomeado primeiroministro quando a Tanganica se tornou semi-independente, em 1959, e tornou-se o primeiro presidente do país após a libertação, em 1962. Foi um dos responsáveis pela articulação política que conduziu à união entre a Tanganica e Zanzibar, levando à constituição da República Unida da Tanzânia, em 1964. Foi também um dos fundadores da Organização da Unidade Africana (OUA).

6 Amílcar Lopes Cabral (1924-1973) nasceu na Guiné-Bissau. Mudou-se com a família para Cabo Verde em 1932. Em 1945, ingressou no Instituto Superior de Agricultura de Lisboa, onde se ligou a grupos anti-fascistas e ao movimento da negritude. Regresso à Guiné-Bissau em 1952. Suas atividades políticas levaram-no a se exilar em Angola, onde se ligou ao Movimento Popular de Libertação de Angola (MPLA). Em 1959, fundou o Partido Africano para a Independência da Guiné e Cabo Verde (PAIGC), que estabeleceu uma delegação na Guiné-Conacri e, em 1963, deu início à luta armada contra a dominação portuguesa. Em 1973, Cabral foi assassinado em Conacri, por dois membros de seu próprio partido. No entanto, a luta armada se intensificou, e no mesmo ano a Guiné-Bissau proclamou unilateralmente a independência.

7 Ahmed Sékou Touré (1922-1984) nasceu na Guiné. Iniciou sua carreira política como sindicalista, e em 1946 passou à militância política. Em 1951, foi eleito para a Assembleia Nacional Francesa, mas sua posse foi barrada pelo governo francês, o mesmo ocorrendo em 1954. Só foi admitido em 1955, depois de ser eleito presidente da Câmara da Guiné-Conacri. Finalmente, o país se declarou independente em 1958, e Touré se tornou presidente, cargo que exerceu até 1984, quando faleceu. 
diretamente na produção, apenas cobrava tributos em produtos ou trabalho das comunidades, que permaneciam autônomas. No entanto, é preciso lembrar que, a despeito de não haver apropriação da terra no sentido estrito, havia apropriação dos homens, por meio da escravidão. De outro lado, o comércio de longa distância era monopolizado por minorias sócio-profissionais ou étnicas, e apesar de não haver interferência na produção, ocorreu, em certa medida, o desenvolvimento de uma mentalidade "capitalista", que teria importante efeito social e cultural.

Diante dessas questões, os africanistas marxistas acabaram por concluir que não havia possibilidade de identificar esse tipo de organização econômica e social com o chamado "modo de produção asiático", criando categorias como "modo tributário de produção" ou "modo de produção de linhagem". No entanto, segundo Person, estas ideias estavam, na verdade, baseadas numa idealização da África antiga (PERSON, 1984, p. 730-732), e o chamado "socialismo africano" acabou por se desenvolver mesclado ao movimento nacionalista, com raízes muito fortes no panafricanismo e na negritude.

De outra parte, há que se levar em conta também a contribuição da URSS e dos países socialistas na luta pela libertação das nações africanas. Com efeito, desde a vitória da Revolução Russa, a URSS procurou apoiar os processos de independência de todos os países colonizados, desenvolvendo uma política de ajuda direta ou indireta. Segundo Iba Der Thiam e James Mulira, no caso da África, esse apoio pode ser dividido em quatro períodos: a) 1917-1945, em que houve uma influência indireta, por meio dos partidos comunistas europeus e do movimento pan-africanista; b) 1945-1965, apoio direto ou indireto aos movimentos de independência e ao estabelecimento dos novos Estados no continente; c) 1965-1975, período em que predominaram ações diplomáticas; e d) a partir de 1975, em que a derrota dos EUA na Guerra do Vietnã levou ao enfraquecimento de sua capacidade de intervenção no continente africano e possibilitou um reforço da influência soviética em algumas regiões, como é o caso de Angola (THIAM; MULIRA, 2011).

Aliás, antes mesmo da vitória da Revolução Russa, a questão do imperialismo e da libertação das colônias vinha sendo discutida pelos bolcheviques. Uma das primeiras abordagens foi feita por Stalin, em 1912. Segundo ele,

(...) os trabalhadores lutam e lutarão contra a política de opressão das nações em todas as suas formas, desde as mais sutis até as mais grosseiras, do mesmo modo que contra a política de atiçar umas nações contra as outras sob todas as suas formas. (...) O direito de autodeterminação significa que só a própria nação tem o direito de determinar seus destinos, que ninguém tem o direito de imiscuir-se pela força na vida de uma nação, de 
destruir suas escolas e demais instituições, de violar seus hábitos e costumes, de perseguir seu idioma, de menosprezar seus direitos. (...) O direito de autodeterminação significa que a nação pode organizar-se conforme seus desejos. Tem o direito de organizar sua vida segundo os princípios da autonomia. (...) A nação é soberana, e todas as nações são iguais em direitos (STALIN, 1979, p. 17-18).

Em 1914, Lenin assim apresentaria a questão:

por autodeterminação das nações entende-se a sua separação estatal das coletividades nacionais estrangeiras, entende-se a formação de um Estado nacional independente. (...) o Estado nacional é a regra e a 'norma' do capitalismo (...). Do ponto de vista das relações nacionais, as melhores condições para o desenvolvimento do capitalismo são proporcionadas, indubitavelmente, pelo Estado nacional. Isto não quer dizer naturalmente que tal Estado, na base das relações burguesas, possa excluir a exploração e a opressão das nações. Isto significa apenas que os marxistas não podem perder de vista os poderosos fatores econômicos, que geram a aspiração à formação de Estados nacionais. Isto significa que a 'autodeterminação das nações' no programa marxista não pode ter, do ponto de vista histórico-econômico, outro significado que não seja a autodeterminação política, a independência estatal, a formação do Estado nacional (LENIN, 1981, p. 512-515).

Essa análise seria ampliada em 1916, com a divulgação de uma de suas obras mais famosas, O imperialismo, fase superior do capitalismo. Nela, Lenin assim se manifestou:

\begin{abstract}
“(...) o imperialismo é, pela sua essência econômica, o capitalismo monopolista. (...) o monopólio nasceu da política colonial. Aos numerosos 'velhos' motivos da política colonial, o capital financeiro acrescentou a luta pelas fontes de matérias primas, pela exportação de capitais, pelas 'esferas de influência', isto é, as esferas de transações lucrativas, de concessões, de lucros monopolistas, etc., e, finalmente, pelo território econômico em geral. Quando as colônias das potências europeias em África, por exemplo, representavam a décima parte desse continente, como acontecia ainda em 1876, a política colonial podia desenvolver-se de uma forma não monopolista, pela 'livre conquista', poderse-ia dizer, de territórios. Mas quando $9 / 10$ da África estavam já ocupados (por volta de 1900), quando todo o mundo estava já repartido, começou inevitavelmente a era da posse monopolista das colônias e, por conseguinte, de luta particularmente aguda pela divisão e pela nova partilha do mundo (LENIN, 1982, p. 667-668).
\end{abstract}

E em 1924, Stalin retomaria a análise de Lenin sobre a questão da autodeterminação dos povos. Segundo ele,

O leninismo ampliou o conceito da autodeterminação, interpretando-o como o direito dos povos oprimidos dos países dependentes e das colônias à separação completa, como o direito das nações à existência como Estados independentes. (...) O leninismo (...) reconhece a existência de capacidade revolucionária no seio do movimento de libertação nacional dos países oprimidos e considera possível utilizá-la no interesse da derrubada do inimigo comum, o imperialismo. (...) Ao resolver a questão nacional, o leninismo parte das 
seguintes teses: a) o mundo está dividido em dois campos: de um lado, um punhado de nações civilizadas, que detêm o capital financeiro e exploram a enorme maioria da população do globo; de outro, os povos oprimidos e explorados das colônias e dos países dependentes, que constituem esta maioria; b) as colônias e os países dependentes, oprimidos e explorados pelo capital financeiro, constituem uma imensa reserva e o mais importante manancial de forças do imperialismo; c) a luta revolucionária dos povos oprimidos dos países dependentes e coloniais contra o imperialismo é a única via pela qual podem libertar-se da opressão e da exploração; d) os principais países coloniais e dependentes já iniciaram o movimento de libertação nacional, que não pode deixar de conduzir à crise do capitalismo mundial; e) os interesses do movimento proletário nos países avançados e do movimento de libertação nacional nas colônias exigem a união desses dois aspectos do movimento revolucionário numa frente comum de luta contra o inimigo comum, contra o imperialismo; f) a vitória da classe operária nos países avançados e a libertação dos povos oprimidos do jugo do imperialismo não são possíveis sem a formação e a consolidação de uma frente revolucionária comum; g) a formação de uma frente revolucionária comum não é possível sem o apoio direto e decisivo, por parte do proletariado dos países opressores, ao movimento de libertação dos povos oprimidos, contra o imperialismo (...); esse apoio consiste em defender, sustentar e pôr em prática a palavra de ordem do direito das nações à separação, à existência como Estados independentes (...) (STALIN, 1924).

Como se vê, os bolcheviques sempre se preocuparam com a questão colonial e com a necessidade de apoio aos movimentos de libertação das colônias como parte de uma luta mais ampla contra o imperialismo. Dessa forma, os africanos foram estimulados a integrar uma frente anti-imperialista, e o Komintern procurou estabelecer relações com as primeiras organizações de caráter nacionalista surgidas no continente, tais como o Congresso Nacional da África Ocidental Britânica, a Associação Central Kikuyo ou o Congresso Nacional Africano (CNA). Note-se, porém, que dada a quase inexistência de uma classe operária africana na época, o Komintern reconhecia que esses movimentos eram dirigidos por setores progressistas da burguesia (THIAM; MULIRA, 2011).

Ademais, a URSS procurou se aproximar de negros norte-americanos e antilhanos, participantes do movimento pan-africanista, bem como dos partidos comunistas das metrópoles com o objetivo de difundir o socialismo. O Partido Comunista Francês (PCF) teve papel importante nessa difusão, levando ao aumento da participação de africanos no movimento comunista internacional. E, com vistas a promover a formação ideológica e política, foi criada em Moscou, em 1930, a escola Stalin de preparação de quadros marxistas.

Quanto ao Partido Comunista Britânico (BCP), teve influência na formação de africanos que estudaram na Inglaterra, tais como Jomo Kenyatta ${ }^{8}$, do Quênia, e Kwame Nkrumah, da Costa do

8 Jomo Kenyatta (1894-1978), professor, jornalista, economista e antropólogo queniano, estudou na Inglaterra e em Moscou. Líder dos kikuyos, em 1946 fundou a Federação Pan-Africana juntamente com Kwame Nkrumah. Tornou- 
Ouro, que, no futuro, teriam papel de destaque nos movimentos de independência de seus países. Já na África lusa, o Partido Comunista Português (PCP) formou vários intelectuais marxistas africanos, entre os quais destacam-se Agostinho Neto ${ }^{9}$, fundador do Movimento Popular de Libertação de Angola (MPLA), e Amílcar Cabral, que liderou a organização do Partido Africano para a Independência da Guiné e Cabo Verde (PAIGC) (THIAM; MULIRA, 2011).

Na segunda fase, ou seja, de 1945 a 1965, verificou-se um grande avanço do movimento nacionalista africano e do anticolonialismo. A URSS contribuiu para o sucesso desses movimentos, inclusive do ponto de vista do estímulo aos estudos sobre a História da África. Tanto assim que o Instituto Etnográfico de Leningrado, atual São Petersburgo, passou a desenvolver um programa sistemático de pesquisa, publicando toda a documentação conhecida sobre a África subsaariana a partir do século XI.

Todavia, para os marxistas, a África apresentava um problema teórico importante: tendo em vista a fragilidade da classe operária no continente, a quem caberia a direção do movimento de libertação? Alguns autores soviéticos não acreditavam na possibilidade de a burguesia africana dirigir o movimento. Contudo, a URSS acabaria por adotar uma postura mais pragmática, apoiando a luta conduzida por setores da burguesia e da intelectualidade africanas, e engajando-se no processo de descolonização. Dessa forma, fornecia assistência material e diplomática a organizações africanas e às nações que lutavam pela libertação. Segundo Iba Der Thiam e James Mulira, dentre as organizações que receberam auxílio soviético estão o Convention People’s Party (CPP), de Gana, o Movimento Mau-Mau e a União Nacional Africana do Quênia (KANU), ambos do Quênia, o National Council of Nigeria and the Cameroons (NCNC), da Nigéria, o Congresso Nacional Ugandense (CNU), de Uganda, o Parti Africain de l'Independence (PAI) e a Union des Populations de Cameroun (UPC), de Camarões, o Parti du Congres de l'Independence (AKFM), de Madagáscar, a Frente de Libertação Nacional (FLN), da Argélia, a Frente de Libertação de Moçambique (FRELIMO), o MPLA, de Angola, a Zimbabwe African People's Union (ZAPU) e a

se presidente da União Africana do Quênia (KAU), em 1947. Participou da revolta Mau-Mau e foi preso em 1952, sendo condenado, em 1953, a sete anos de trabalhos forçados. Em 1961, a União Nacional Africana do Quênia (KANU) e a União Democrática Africana do Quênia (KADU), os dois partidos que sucederam o KAU, exigiram a libertação de Kenyatta. Foi solto no mesmo ano e, em 1962, assumiu uma cadeira no Parlamento. Nas eleições de 1963, o KANU saiu vencedor, e Kenyatta tornou-se primeiro-ministro do governo autônomo do Quênia. Em 1964, com a proclamação da independência, Kenyatta elegeu-se o primeiro presidente do país. Foi reeleito em $1966 \mathrm{e}$ 1974, falecendo em 1978.

9 Antonio Agostinho Neto (1922-1979) nasceu em Angola. Médico, estudou em Lisboa e Coimbra. Preso pela polícia política portuguesa, foi deportado para Cabo Verde. Posteriormente, foi-lhe permitido fixar residência em Portugal, de onde fugiu para o exílio e assumiu a direção do MPLA. Obtida a independência em 1975, tornou-se o primeiro presidente de Angola, cargo que exerceu até sua morte, em 1979, em Moscou. 
Zimbabwe African National Union (ZANU), do Zimbábue, o CNA, da África do Sul, e a South West African People’s Organization (SWAPO), da Namíbia (THIAM; MULIRA, 2011, p. 970).

O apoio da URSS aos movimentos de libertação da África ficaram explícitos nas resoluções adotadas tanto no XXI Congresso do Partido Comunista da União Soviética (PCUS), em 1959, quanto no seu XXII Congresso, em 1961. Essas decisões coincidiram com uma forte investida diplomática da URSS perante a Assembléia Geral da Organização das Nações Unidas (ONU), de 1960, quando apresentou proposta de resolução - que foi adotada em 1961 -, pela qual todas as metrópoles eram convocadas a conceder independência às suas colônias.

No terceiro período, de 1965 a 1975, as ações soviéticas na África foram principalmente de cunho diplomático e assistencial, e a URSS assinou dezenas de acordos com as jovens nações africanas com vistas a fornecer ajuda a estes países. Esse auxílio se concentrou principalmente nas áreas de ensino e pesquisa. Dessa forma, cerca de 30.000 africanos foram estudar na URSS, ao mesmo tempo em que professores e pesquisadores soviéticos eram enviados para a África com o objetivo de ensinar e desenvolver centros de pesquisas nas universidades do continente (THIAM; MULIRA, 2011, p. 971-972).

Finalmente, no quarto período, diante da derrota dos EUA no Vietnã, reduziu-se a interferência daquele país na África. Dessa forma, a URSS procurou ampliar sua influência, dando ênfase à luta em países cuja libertação completa sofria grave ameaça, tendo em vista a existência de movimentos guerrilheiros que defendiam a submissão econômica aos norte-americanos, como é o caso de Angola. Também a resistência ao racismo, como a luta do CNA contra o regime de apartheid na África do Sul, recebeu apoio da URSS.

\section{O NEOCOLONIALISMO E A QUESTÃO DA CHINA}

Apesar de toda a ajuda soviética aos movimentos de libertação e ao processo de construção dos novos Estados africanos, o fim da guerra fria e do socialismo real, com a queda do Muro de Berlim, em 1989, e o desmoronamento da URSS, em 1991, bem como o triunfo do neoliberalismo, levariam novamente as nações africanas à quase completa subordinação econômica aos países capitalistas centrais.

Com efeito, imediatamente após a independência, diversas formas de pilhagem permaneceram, ainda que de maneira mais difusa, por meio do chamado neocolonialismo. Aliás, um 
dos primeiros a denunciar o fenômeno foi o líder ganense, Kwame Nkrumah, para quem " $a$ essência do neocolonialismo é que um Estado que é teoricamente independente e dotado de todos os atributos da soberania tem, na realidade, sua politica dirigida do exterior" (NKRUMAH apud FERRO, 1996, p. 395).

De fato, e a despeito do apoio da URSS a diversos países, a extração de riquezas continuou por meio das trocas desiguais e dos baixíssimos salários pagos pelas corporações estrangeiras estabelecidas nas ex-colônias. Isso levou a um processo de emigração forçada, ou até mesmo encorajada, que permitia o fornecimento de mão de obra barata nos territórios das antigas metrópoles. Da mesma forma, a falta de oportunidades provocou um verdadeiro êxodo de cérebros, transformando-se em mais uma forma de exploração, uma vez que permitia aos países industrializados receber pessoal capacitado sem os gastos para sua formação, e pagando, evidentemente, salários muito mais baixos do que aqueles exigidos por seus próprios quadros.

Outra forma de manutenção da pilhagem depois da independência se deu por intermédio do comércio mundial, porquanto a tendência de queda dos preços internacionais de matérias primas e produtos agrícolas favoreceu as antigas metrópoles nas trocas com as ex-colônias, não só pelo fato de os produtos industrializados alcançarem preços mais altos, mas também pelo superfaturamento desses artigos, de bens de consumo e de equipamentos. A exploração foi, ademais, reforçada por meio de fretes, comissões, juros bancários, transferência de tecnologia, etc. Segundo Marc Ferro, as indústrias das metrópoles tiveram seus “ 'três decênios gloriosos' após a desloconização” (FERRO, 1996, p. 392).

Esta situação tornou-se extremamente grave a partir dos choques do petróleo da década de 1970 e da crise econômica que se abateu sobre os países centrais do sistema capitalista, que alteraram suas políticas econômicas e redirecionaram seus investimentos. A partir de então, a África foi praticamente “esquecida" por suas antigas metrópoles, tanto que, no período compreendido entre 1965 e 1983, o continente recebeu apenas 3\% do total de investimentos mundiais (COQUERYVIDROVITCH, 2011, p. 360). Como bem assinalou Catherine Coquery-Vidrovitch,

o início dos anos de 1980 marcou um agravamento preocupante da situação, acelerado pela grande estiagem que, entre 1983 e 1985, afligiu 20 países e cerca de 35 milhões de pessoas. Nas últimas décadas do século XX, a baixa nos rendimentos per capita e a instabilidade nos déficits internos foram de tal ordem que as reservas, as quais ainda correspondiam a $15 \%$ do Produto Nacional Bruto (PNB), havia dez anos, caíram, rebaixando-se a taxas (...) equivalentes a $6 \%$ do total. Ora, simultaneamente, os fluxos líquidos de capitais externos reduziram-se perigosamente COQUERY-VIDROVITCH, 2011, p. 360). 
Em suma, na década de 1980, a situação era tão grave que Edem Kodjovi Kodjo, então secretário-geral da Organização da Unidade Africana (OUA) declarou: "A África está morrendo (...). O porvir parece-nos sem futuro" (KODJO apud COQUERY-VIDROVITCH, 2011, p. 362). A única alternativa para a retomada do fluxo de investimentos e de concessão de empréstimos parecia ser os países africanos se submeterem inteiramente aos ditames do Fundo Monetário Internacional (FMI) e do Banco Mundial (BIRD), abrindo mão da soberania tão duramente conseguida. Hoje, parece que o comércio sino-africano e os investimentos chineses no continente estão contribuindo para a superação da crise e proporcionando crescimento às economias africanas.

Diante desses elementos, cabe aqui a pergunta: estaria a China implementando uma política imperialista ou neocolonialista em relação à África? A esse respeito, muitas têm sido as acusações, principalmente da parte de alguns países e empresas ocidentais, cujos interesses comerciais no continente têm sido prejudicados em virtude da concorrência chinesa.

De fato, após o colapso da URSS, houve um grande crescimento das relações comerciais sino-africanas, e o volume dos investimentos chineses no continente, que se acentuaram marcadamente a partir de 2000, vêm mudando a face da África. Depois de duas décadas de absoluta penúria, as populações de diversos países têm, agora, acesso a manufaturados baratos, e conquistaram um mercado seguro para exportações, notadamente de produtos primários.

No caso do petróleo, os interesses da China são claros: garantir abastecimento para a continuidade do crescimento econômico e, no futuro, assumir capacidade de intervenção no mercado mundial de óleo. Tendo em vista esses objetivos, o governo chinês desenvolve uma política agressiva, estabelecendo contratos com diversos países do mundo, inclusive da África, não se atendo às críticas ocidentais e às pressões e boicotes estabelecidos por organismos internacionais. Para a China, a questão do abastecimento de petróleo é estratégica, e as autoridades do país não tecem grandes considerações éticas, morais, humanitárias e ambientais antes de assinar os acordos (MENDONÇA, 2011).

De outra parte, o estreitamento dos laços financeiros e comerciais com a China não tem evitado o aparecimento de tensões na África, as quais se manifestam de várias formas e por diversos motivos. Exemplos disso são o ataque guerrilheiro realizado em abril de 2004 a um campo de petróleo na Etiópia, que provocou a morte de 77 pessoas, bem como as dezenas de trabalhadores e 
engenheiros chineses, além de outros civis mortos e seqüestrados, desde 2005, na Nigéria e no Quênia (DALY).

Nesse sentido, um aspecto que deve se salientado é o fato de que a entrada maciça de produtos baratos chineses tem provocado prejuízos para indústrias têxteis e manufaturas de baixa tecnologia africanas, que não conseguem enfrentar a concorrência. Do mesmo modo, há atritos relacionados à disputa por mercados com redes de lojas retalhistas chinesas e à prática de empresas do país levarem seus próprios trabalhadores para a realização dos projetos contratados. O resultado tem sido o surgimento de protestos por todo o continente, alguns deles extremamente violentos.

Embora determinados aspectos das relações sino-africanas possam acarretar desvantagens para o continente, é preciso considerar a gravidade da situação em que se encontrava a África na década de 1980, e cujos principais traços já foram mencionados. Durante muitos anos, os investimentos chineses representaram praticamente a única alternativa para a miséria cada vez maior das populações africanas, e efetivamente proporcionaram a retomada do crescimento econômico em diversos países.

O fato de a China não se limitar a fazer "doações" não significa, em hipótese alguma, uma atitude imperialista ou neocolonialista, e por várias razões: primeiramente, há que se considerar que a China, embora seja hoje a segunda economia do mundo, permanece um país pobre, com uma imensa população que ainda não tem acesso ao consumo e ao atendimento de necessidades básicas. Em segundo lugar, os contratos firmados entre empresas chinesas e os governos africanos sempre garantem algumas vantagens a estes últimos, notadamente no que se refere à construção de obras de infraestrutura, à ajuda médica, e à colaboração técnica e educacional.

Por outro lado, os recursos provêem de empresas estatais chinesas, financiadas por bancos estatais chineses, e a decisão de investimento não parte do capital financeiro. Da mesma forma, Pequim não interfere na política interna dos países africanos, negociando com seus governos independentemente da orientação seguida. Finalmente, não há qualquer sinal de tentativa de conquista de territórios, pelo contrário: as aquisições de terras africanas por parte de empresas chinesas se dão mediante contratos de compra e venda ou de arrendamento.

Destarte, as acusações por atitudes supostamente "imperialistas" ou "neocolonialistas" da China em relação à África são totalmente improcedentes, e revelam muito mais uma tentativa de manter o continente à mercê dos interesses econômicos das antigas metrópoles e de suas empresas, 
garantindo-lhes a perpetuação do acesso ilimitado e irrestrito às fontes aparentemente inesgotáveis das riquezas africanas. Ou seja: os interesses e investimentos da China na África parecem estar hoje colocando obstáculos à continuidade da exploração imperialista e neocolonialista por parte de governos e empresas ocidentais.

\section{CONSIDERAÇÕES FINAIS}

O processo de emancipação da maioria dos países da África foi concluído em apenas 11 anos. De fato, no período compreendido entre 1957 e 1968, quase todas as nações do continente haviam alcançado a sua independência.

No entanto, os Estados nacionais constituídos a partir de então seriam organizados como sucessores das antigas colônias, cujas fronteiras haviam sido definidas ainda no século XIX pelos países europeus. Por outro lado, a própria falta de quadros locais para organizar a administração pública levou à permanência da subordinação às antigas metrópoles. Finalmente, a economia das jovens nações manteve integralmente a estrutura colonial, baseada na produção primária e na importação de artigos manufaturados. Isso acabou por condená-las ao subdesenvolvimento e à dependência econômica em relação aos países capitalistas centrais.

A URSS, que tivera papel essencial na luta pela independência, também contribuiu enormemente para amenizar essa situação. Com efeito, entre 1965 e 1975, o país assinou dezenas de acordos com as jovens nações africanas com vistas a fornecer ajuda a estes países, principalmente nas áreas de ensino e pesquisa. No entanto, o fim do socialismo real parecia agravar inexoravelmente a crise iniciada na década de 1970, a partir dos choques do petróleo, e que foi acentuada no decênio de 1980, quando as antigas metrópoles e demais países ocidentais retiraram ou suspenderam os investimentos no continente.

Foi somente a partir do incremento das relações comerciais entre a África e a China, nos anos de 1990, que os países africanos puderam iniciar um processo de recuperação de sua economia, criando condições mais favoráveis para o conjunto de sua população. Durante muitos anos, os investimentos chineses representaram praticamente a única alternativa para a miséria cada vez maior das populações africanas, e efetivamente proporcionaram a retomada do crescimento econômico em diversos países.

Mas, contrariamente às frequentes acusações feitas por empresas e governos ocidentais, de 
que a China estaria praticando uma política imperialista ou neocolonialista em relação à África, é preciso levar em conta que os contratos firmados entre as firmas chinesas e os governos africanos sempre garantem algumas vantagens a estes últimos, notadamente no que se refere à construção de obras de infraestrutura, à ajuda médica, e à colaboração técnica e educacional. Ou seja, depois da 1991, a China substituiu a URSS no que tange a todo e qualquer auxílio ao continente africano, contrariamente ao que sempre fizeram as antigas metrópoles e os países ocidentais.

\section{REFERÊNCIAS}

APPIAH, Kwame Anthony. Na casa de meu pai: a África na filosofia da cultura. Rio de Janeiro: Contraponto, 1997.

ARENDT, Hannah. Imperialismo In: As origens do totalitarismo. São Paulo: Companhia das Letras, 1989.

COQUERY-VIDROVITCH, Catherine. As mudanças econômicas na África em seu contexto mundial (1935-1980) In: MAZRUI, Ali A. (Org.). História geral da África: a África desde 1935. São Paulo/Brasília: Cortez/ UNESCO, 2011, v. 8.

DALY, John C. K. Feeding the dragon: China's quest for african minerals (disponível em: $<$ http:// www.frankhaugwitz.eu/doks/security/2008_01_China_Quest for_Minerals in_Africa_Jamestow n.pdf>, acesso em: 21/5/2010).

DECRAENE, Philippe. O panafricanismo e as grandes potências In: GOMES, I. da Conceição, FRAGOSO, Mário (Org.), org. A nova África. São Paulo: Anhambi, 1961.

DESCHAMPS, Hubert. Da dependência à independência e à interdependência In: A nova África. São Paulo: Anhambi, 1961, p. 199.

FANON, Frantz. Os condenados da terra. Rio de Janeiro: Civilização Brasileira, 1979.

FERRO, Marc. História das colonizações: das conquistas às independências (séculos XIII a XX). São Paulo: Companhia das Letras, 1996.

FREUND, Bill. The making of contemporary Africa: the development of african society since 1800. Londres: MacMillan Press, 1998.

HERNANDEZ, Leila Maria Gonçalves Leite. Os filhos da terra do sol: a formação do Estadonação em Cabo Verde. São Paulo: Summus, 2002.

ILIFFE, John. Africans: a history of a continent. Cambridge: Cambridge University Press, 1995.

KI-ZERBO, Joseph. História da África negra. Lisboa. Publicações Europa-América, s. d., v. 2. 
LENIN, V. I. Sobre o direito das nações à autodeterminação In: Obras escolhidas. São Paulo: AlfaÔmega, 1982, v. 1.

LENIN, V. I. O imperialismo, fase superior do capitalismo In: Obras escolhidas. São Paulo: AlfaÔmega, 1982, v. 1.

MEMMI, Albert. Retrato do colonizado precedido do retrato do colonizador. Rio de Janeiro: Paz e Terra, 1967

MENDONÇA, Marina Gusmão de. Impactos dos interesses petrolíferos nas relações comerciais China-África. Sankofa. São Paulo, ano IV, nº 7, julho/2011.

PERSON, Yves. O socialismo na África negra In: DROZ, Jacques (Org.). História geral do socialismo. Lisboa: Horizonte, 1984, v. 9, cap. 3.

RALSTON, Richard David, MOURÃO, F. A. A. A África e o Novo Mundo In: BOAHEN, A. Adu (Org.). História geral da África: a África sob dominação colonial (1880-1935). São Paulo: Ática/UNESCO, 1991, v. 7, cap. 29.

SENGHOR, Léopold-Sédar. Quando a África perguntava: suportar ou escolher In: GOMES, I. da Conceição, FRAGOSO, Mário, org. A nova África. São Paulo: Anhambi, 1961.

SPENCER, Herbert. El hombre contra el Estado. Buenos Aires: Aguilar, 1963..

STALIN, J. A questão nacional In: Sobre os fundamentos do leninismo (disponível em:

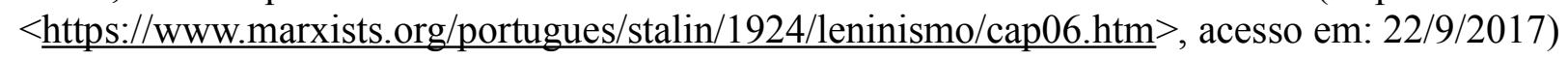

STALIN, J. O movimento nacional In: O marxismo e o problema nacional e colonial. São Paulo: Ciências Humanas, 1979.

THIAM, Iba Der; MULIRA, James. A África e os países socialistas In: MAZRUI, Ali A.; WONDJI, C. (Org.). História geral da África: África desde 1935. São Paulo/Brasília: Cortez/UNESCO, 2011, v. 8, cap. 27. 